Article

\title{
Politics of Multilingualism in Roma Education in Early Soviet Union and Its Current Projections
}

\author{
Elena Marushiakova * and Vesselin Popov \\ School of History, University of St. Andrews, St. Andrews, KY16 9BA, UK; E-Mails: emp9@st-andrews.ac.uk (E.M.), \\ vp43@st-andrews.ac.uk (V.P.) \\ * Corresponding author
}

Submitted: 14 August 2017 | Accepted: 16 October 2017 | Published: 22 December 2017

\begin{abstract}
This article presents the history of the politics of multilingualism (or lack thereof) in regard to Roma (formerly known as 'Gypsies'). In the 1920s and 1930s in the newly established Union of Soviet Socialist Republics, against a backdrop of proclaimed principles of full equality of all peoples ${ }^{1}$ living in the new state, commenced a rapid creation of schools for Roma children with instruction in Romani mother-tongue along with special training of Roma teachers. The results achieved were impressive in regard to the general literacy of Roma communities, but nevertheless in 1938 the 'Gypsy schools' have been closed and Roma children were enrolled into mainstream schools lacking any elements of multilingualism. After World War II individual countries of Eastern Europe implemented various forms of special education for Roma children, neither of which however with elements of multilingualism. Only after the collapse of communist regimes in Eastern Europe, in the conditions of transition and the subsequent Euro-integration, various singular countries in the region have developed individual elements of multilingualism and educational policies targeting Roma children (e.g., introducing under various forms a Romani language instruction). Sporadically there even appeared proposals for teaching instruction conducted entirely in Roma mother-tongue, which were debated and rejected (including by Roma themselves).
\end{abstract}

\section{Keywords}

education; Gypsies; language; multilingualism; Roma; Romani language; school; USSR

\section{Issue}

This article is part of the issue "Multilingualism and Social Inclusion", edited by László Marácz (University of Amsterdam, The Netherlands/Gumilyov Eurasian National University, Kazakhstan) and Silvia Adamo (University of Copenhagen, Denmark).

(C) 2017 by the authors; licensee Cogitatio (Lisbon, Portugal). This article is licensed under a Creative Commons Attribution 4.0 International License (CC BY).

\section{Introduction}

The so-called Great October Socialist Revolution in 1917 and the subsequent Civil War (1918-1921) led to radical social changes. The former Russian Empire was replaced by a new, fundamentally different state, the Union of the Soviet Socialist Republics (USSR, officially as of 1922), characterised by new economic relations, social structure and reality. The authorities started to pay more attention to the national and ethnic issues in this vast coun- try populated by tens of different peoples. The dominant Government line towards these issues was the 'Leninist' national policy (designated in contemporary academia usually as 'Korenizatsiya' ${ }^{2}$ ), based on the principles of equal rights for the individual peoples of the USSR and comprehensive support for their national development, including the creation of a written language and literature for those people that have been lacking it until then (Hirsch, 2005; Martin, 2001; Slezkine, 1994; Suny \& Martin, 2002;). These fundamental principles, however,

\footnotetext{
${ }^{1}$ The term 'narod' used in the Soviet Union is translated here as 'people', to designate nation, nationality, ethnic group, citizens, etc. For historical accuracy, we keep this term also later in the text.

2 'Korenizatsiya' translated literally from Russian is 'putting down roots'. It corresponds to the Russian term 'korennoe naselenie' [root population] used for native/indigenous population. The policy of 'korenizatsiya' implied promotion of indigenous people, development and introduction of local languages, and support of native culture.
} 
were applied differently, depending on the specific interests of each Soviet state and those of the individual communities. A typical example in this regard is the national policy in the USSR regarding Gypsies.

At this point a terminological clarification is needed. In the Russian Empire, and later on also in the USSR, the official name of the community is Tsygane, usually translated into English as 'Gypsies' (in spite of some differences in the meaning of this word). The designation Tsygane, however, includes not only Roma communities (and small number of Sinti merging with Roma), but also the Lom (named by the surrounding population Bosha or Posha) and Dom (named by the surrounding population Garachi or Karachi) communities in the South Caucasus, as well as Mughat (named by the surrounding population Lyuli or Jughi) and other 'Gypsy-like' communities (Mazang, Tavoktarosh or Sogutarosh, Agha, etc.) in Central Asia (Marushiakova \& Popov, 2016). The policy of the Soviet state, however, in practice was directed almost exclusively at Roma (and only to a lesser extent, to other communities), i.e., in this particular case the terms Roma and Gypsies can be regarded and used as synonyms; and, therefore, in the text bellow we will stick to the terminology of the sources.

According to the 1926 population Census in the USSR, the total number of Gypsies at the time was 61,299, of whom $64.2 \%$ (40,900 people) identified Romani language (Romanes) as their mother tongue; a relatively small number of Gypsies, 20.9\%, lived in towns and cities, more than two-thirds of them were still nomadic (Crowe, 1996, pp. 175-176; Perepisi naselenia Rossiiskoi..., 2012; Wixman, 1984, p. 40). The Gypsies, who were city dwellers, were in their vast majority members of the Gypsy musical and artistic elite established already in the times of the Russian Empire and closely linked to the top social estates in the former Russian Empire. Palpable, those Gypsies who lived in the large cities were the first who started to be engaged with social and political activities in the new state. They were the first ones to go under the banner of the new communist, proletarian ideology. Under the control and by the practical guidance of the Communist Party and the Soviet state in 1925 was established the All-Russian Union of Gypsies (Crowe, 1996, p. 192; Druts \& Gessler, 1990, p. 281; Kalinin, 2005, p. 36; Kenrick, 2007, p. 259; O'Keeffe, 2013, p. 41; Rom-Lebedev, 1990, p. 163), an organisation which existed only for a relatively short period of time but nevertheless succeeded to accomplish numerous tasks. It was dissolved by a Decree of the People's Commissariat for Internal Affairs from 15 February 1928 (Demeter, Bessonov, \& Kutenkov, 2000, p. 205; Druts \& Gessler, 1990, p. 281; O'Keeffe, 2013, p. 60), but most of the AllRussian Union of Gypsies members, including the bulk of its leadership, continued to be involved in Soviet policy in different ways. In fact, the dissolution of the Union did not influence the Government's policies towards Roma, and even more, this policy became quite more active and more efficient.

\section{Codification of Romani Language and Romani Literature in USSR}

An important component of the national policy of the Soviet state with regard to the Gypsies was the development of a standardised codified Romani language and literature and, on that basis, the comprehensive education of the Gypsies. Similar policies for the creation of a written language and literature applied then for many other peoples, but what makes the Gypsy case unique is that unlike other ethnicities without own codified written language the Gypsies didn't live compactly on a certain administrative territory and the majority of them led a nomadic way of life. Thus, education could encompass relatively easy only a small segment of Romathose who lived in cities or in collective farms, the socalled kolkhozes, dispersed on the vast territory of the new state.

Gypsy education was set to develop on the basis of own language, which until then existed only as oral one; thus, the primary task became the issue of turning the Romani language into a literary writing language. On 8 June 1925, the daily broadsheet newspaper Izvestia ${ }^{3}$ [in translation 'delivered messages'], a newspaper which expressed the official views of the Soviet government (as published by the Presidium of the Supreme Soviet of the USSR) issued an article devoted to the development of literature and international relations. This article expressly listed Gypsies among these peoples who are entitled to receive education in their own language. In 1926 a research section was set up at the All-Russian Union of Gypsies, which however failed to do any substantive work. Activities became more substantive when the Government stepped in. In 1926 again the Izvestia newspaper published an article 'Ob obraztsakh tsiganskoy pismennosti' [On the samples of the Gypsy script], which described the first version of the Gypsy alphabet, and standardised and codified language developed by Nikolay Pankov and Nina Dudarova on the basis of the dialect of the Ruska Roma (Kalinin, 2005, p. 42).

After Anatoliy Lunacharskiy, the head of the People's Commissariat on Education (Narkompros) of the Russian Soviet Federative Socialist Republic, issued the Decree on Creating a Gypsy Alphabet on 10 May 1927 (O'Keeffe, 2013, pp. 79-80), there was a meeting between representatives of Glavnauka [The Chief Directorate of Science at the Narkompros], Sovnatsmen [The Council on National Minorities] and the All-Russian Union of Gypsies. At the meeting, which was held in May 1927, it was decided to develop a Gypsy alphabet on the basis of the Russian alphabet and a Committee was established to work

\footnotetext{
${ }^{3}$ The full title of the Newspaper during this period of time (1923-1938) is Izvestiya TSIK SSSR i VTSIK Sovetov rabochikh, krestyanskikh, krasnoarmeyskikh $i$ kazachikh deputatov [Delivered messages of the Central Executive Committee of the USSR and the All-Russian Central Executive Committee of the Soviets of Workers', Peasants', Red Army and Cossack Deputies].
} 
on the development of the Gypsy literary language. The committee consisted of Prof. Maxim Sergievskiy from Moscow State University, his assistant Tatyana Venttsel, N. Rogozhev, and two All-Russian Union of Gypsies members-Nikolay Pankov and Nina Dudarova (Druts \& Gessler, 1990, p. 295). A Commission on Gypsy Studies was established in 1927. The Commission was a division of the Institute for Teaching Methods and was responsible for coordinating teaching and publishing activities of works in Romani language.

The Commission was quite active. Prof. Maxim Sergievskiy prepared a Gypsy Grammar (Sergievskiy, 1931), followed by a Gypsy-Russian Dictionary compiled by Maxim Sergievskiy and Aleksey Barannikov (1938) under the editorship of Nikolay Pankov. The Romany Zoria [Gypsy Dawn] journal came out in 1927, with a total of four issues (published at irregular intervals). In 1930 this magazine was replaced by the Nevo Drom [New Way] which had 24 issues by 1932. In 1932 the first (and last) issue of the Butiaritko Rom [The Working Gypsy] journal (Kalinin, 2005, p. 43) was published. The journals were written exclusively in the Romani language and contained all sorts and all literature genres including Gypsy folklore and literary works.

Publishing literature in the Romani language was a quite impressive activity. A Gypsy department was set up at the Tsentrizdat [The Central Publishing House] in 1930. It published the following main types of literature: socio-political; Marxist and Leninist; kolkhoz; industrial and technical; popular science; fiction (by Gypsy authors or translations in Romani of classics). By 1932 there were already Gypsy departments in four other publishing houses: Selkolkhozgiz, publishing books and brochures about kolkhoz-related and agricultural issues; Molodaya Gvardia-publications for students and young people, established by the initiative of the Central Committee of the All-Union Leninist Young Communist League; GIHLO [State Publishing House for Fiction]; and Uchpedgiz - text books and teaching aids for Gypsy schools and for adult training. In 1936 a total of eight publishing houses had published books in the Romani language (Kalinin, 2005, p. 49).

The total number of books issued in Romani language between 1931 and 1938 was around 250 (Rusakov \& Kalinin, 2006, pp. 266-287; Zahova, 2014, pp. 130-141). These publications were diverse; quite a few of them were Soviet-era propaganda with revealing titles, e.g., Amaro znamyo-Lenino [Our Banner-Lenin], Rakiribe vash leninizmo [Conversation about Leninism], Palo vlast Soveten [About the Soviets' Rule], Koli vrago na zdelape les haskirna [which is translation of the famous article by Maxim Gorky, If the Enemy Does Not Surrender He Is Destroyed], So diya sovetsko vlast Romanechyake [What the Soviet Rule Gave to the Gypsy Girls], etc. (Anonymus, 1933; Bezlyudsko, 1932a; Dudarova, 1929; Gorky, 1931; Karpinsko, 1934).

There were many literary works which aimed at educating Gypsies about kolkhozes, agriculture, various as- pects of factory work and different occupations. A number of publications were dedicated to practical problems in the life of a Gypsy family, e.g., Pervo pomoshch dro nabahtalo sluchyai [First Aid in Case of an Accident], Dzhyuvlyakiri gigiena [Women's Hygiene], etc. (Berlyando, 1931; Levi, 1935). There were, however, some educational publications which could hardly be expected to be of any pragmatic interest to Gypsy readers, such as Pal mamontoste [About the Mammoth], Dre rozrodibe palo timinitka minerali te rudi [On the Extraction of Useful Minerals and Ores], etc. (Fedorovskiy, 1933; Dmitrievo, 1935). The fiction that was published contained many translations in Romani of classics, such as books by Alexander Pushkin (short novels, fairy tales, the famous Poem 'Gypsies'), Lev Tolstoy, Prosper Merimee (Carmen), Maxim Gorky (including Makar Chudra), etc. (e.g., Gorko, 1932; Merime, 1935; Pushkin, 1937a, 1937b; Tolstoy, 1933, 1936). There were also more than 40 published books by Roma authors, such as Aleksandar Germano (1930, 1931, 1932, 1934, 1935, 1938); Maxim Bezlyudsko (1932b, 1932c, 1933); Olga Pankova (1933, 1936, 1938); Ivan Rom-Lebedev (1930, 1931); Evdokiya Orlova (1933); Mariya Polyakova (1931); Alexey Svetlovo (1938); Ivan Khrustalyov (1936); Ilyinsko (1932, 1934); Georgiy Lebedevo (1930); and others. The genres of these books included mainly prose and poetry, and theatre plays. It even inspired the beginning of a new genre, which nowadays is especially popular in Romani literature-the comics, with the main character Rom Pupyrka (Polyakova, 1929, p. 49, 1930, p. 63).

There is no doubt that the literature published in the Romani language influenced the development of the Gypsy community. It touched however only a relatively limited layer of the community, concentrated mainly in Moscow. It's understandable that nomadic and illiterate then members of the Gypsy communities did not feel the need for such literature and that the Gypsy activists were unable to distribute the books widely among many of them. Thus, it is hardly any surprise that part of the literature in Romani never reached its intended readership from Gypsy communities and years after part of publications were discovered unopened in some funds of Moscow libraries. ${ }^{4}$ One may ask question why publications with such a low demand were released at all: was it a matter of short-sightedness of authorities, or it was matter of making a political point. The answer is in the spirit of the time: The Soviet government listed Gypsies among those people who are entitled to receive education and literacy in their own language. The prescribed national policy was to publish, and whether somebody read the publications did not matter.

\section{Roma Education in Early Soviet Union}

A great number of publications were devoted to issues of Gypsy education, and numerous textbooks and teaching aids appeared (till now we were able to dis-

\footnotetext{
${ }^{4}$ This observation shared with us late Lev Cherenkov, renowned Romani Studies scholar, in June 2001.
} 
cover 34 of them). A total of 13 primers on Romani language were published (Kalinin, 2005, p. 58), among them not only primers for pupils in Gypsy schools (e.g., Dudarova, 1932b, 1933; Dudarova \& Pankov, 1930), but also for literacy of illiterate Roma adults (e.g., Dudarova, 1928, 1932a, 1934; Pankovo, 1934). The first published primer was Nevo drom. Bukvaryo vash bare manushenge [New Way. Primer for Adult People] by Nina Dudarova and Nikolay Pankov (1928), and this is the first-ever such publication for Gypsies in the world; the last one was Lilvari piro romani chib [Text-book on Roma Language] by Tatyana Venttsel and Aleksandar Germano (1937). Together with this, a number of textbooks in different school disciplines, like literature, mathematics, geography, natural and social sciences, etc. were published (e.g., Dudarova, 1933; Nikitino, Polyakovo \& others, 1932; Pankovo, 1933; Taranovo, 1932; Terekhova \& Erdely, 1934; Tetyurev, 1935).

Gypsy schools used textbooks and teaching aids were written in the dialect of Ruska Roma, which was codified and accepted as standard. This was understandable because in the early Soviet Union the group of Ruska Roma was the most numerous and majority of the Gypsy intelligentsia and activists originated from it. On the territory of the country lived however also other groups speaking different dialects of Romani, such as Servi and Vlaxi in Ukraine, Krimurya, relative new arrived groups of Kelderari and Lovari, small communities of Sinti, Kishiniovtsi, Plashchuni, and along with them non-Romani speaking Gypsy groups of Dayfa, Dom, Lom and Mughat. The members of these Gypsy groups found it more or less difficult to understand the dialect of Ruska Roma and this is why sporadic attempts were made to teach students by using a dialect they understood. Especially known is the work of P. Kravchenko, a teacher who worked in the boarding school at the Krasniy Put [The Red Road)] kolkhoz near the town of Sumi, the Ukraine in 1931, and who taught his students in the dialect of Roma group of Servi (Kalinin, 2005, p. 50).

The second half of the 1920s witnessed a strong drive to bring literacy and education to adult Gypsies and to open Gypsy schools, crèches and kindergartens. Adult training was delivered in different ways: through the socalled likbez [i.e., eliminating illiteracy] actions-when through individual tutoring by members of Komsomol [Communist Youth Organisation] the adults were taught to read and write, and through opening evening classes. Gypsy schools and kindergartens however weren't separate educational establishments, they were often a distinct part of already existing schools. In Moscow, in 1932, functioned three Gypsy schools-in the Proletarskiy, Marina Roshcha and Zamoskvorechye districts. The number of Gypsy schools was unstable because new schools were constantly opened at many places; for instance in Gypsy kolkhozes, but some schools were soon after closed down due to different reasons, such as poor facilities, lack of skilled teachers, and Gypsy children's insufficient interest or because dissolution of individual
Gypsy kolkhozes. The total number of Gypsy schools (or smaller units called Groups of Gypsy Children having the same status as schools) which existed for some time in the USSR between 1926-1938 was 86. In 1938 there was one elementary school (up to 7th grade) and 25 primary Gypsy schools (up to 4th grade), as well as 12 separate Groups of Gypsy Children in some primary schools. In addition to these schools, there was a Gypsy boarding school (in the village of Serebryanka, near the town of Smolensk). Groups of Gypsy Children existed in two additional boarding schools and four children's homes (Druts \& Gessler, 1990, pp. 297-299; Kalinin, 2005, pp. 51-52).

The instruction in Gypsy schools was supposed to be provided only in Romanes and this raised the issue of teacher training. The first Gypsy teachers were trained through Gypsy educational courses introduced in 1927 and were conducted by the first Roma teacher-trainers, Nina Dudarova and Nikolay Pankov. The Qualification Enhancement Institute in Moscow introduced Gypsy pedagogical courses in 1931. The first class consisted of 30 people who had been selected out of 80 candidates on the basis of a competitive examination. These courses were furthered by the so-called Off-site accelerated summer courses in Toropets (Kalinin Region), Nevel (Pskov Region), Serebrianka (near Smolensk), Harkov, Ivanovo, Saratov, Sverdlovsk, Leningrad, Orel....During the same year, a Gypsy Department was founded in the Pedagogical School in the town of Dorogobuzh (Smolensk Region). The department had two sections (training of educators and training of teachers) and total of 28 people had been trained (Bezlyudsko, 1932a; Druts \& Gessler, 1990, pp. 299-300; Kalinin, 2005, pp. 53-54).

The training of teachers for Gypsy schools and the integration of Gypsy children into the educational system increased pace after the Decree of the Narcompros from 18 April 1932 'On the Measures to Boost Training and Education of Gypsy Children and Training Teachers for Gypsy Schools'. As a result of this Decree, the Gypsy pedagogical courses in Moscow were reorganised into a Pedagogical Vocational School with a Gypsy department. By 1938 the new vocational school had trained between 120 and 140 (different sources give different figures) Gypsy teachers (Druts \& Gessler, 1990, p. 300; Kalinin, 2005, p. 54).

The work in the Gypsy schools was accompanied by some specific problems. The archives preserve a number of documents reflecting difficulties of these schools and of the Gypsy Pedagogical Vocational School (GARF, f. P-1235, o. 127, d. 8). On the one hand, the vocational school's management constantly asked for new premises or repairs of the old school equipment, for more students' scholarships, more places in student boarding houses, etc. On the other hand, however, there are numerous reports which communicate the attitude of Roma parents towards Gypsy schools. In many places in the country (and especially in the cities) the parents did not want their children to be educated in Gypsy schools; they preferred to send them to the mainstream schools, 
which were thought to secure better inclusion in the society. These reports were the first warning about ushering of divergence in the visions for the development of Roma education (and more generally the overall development of the community) between the 'new Soviet Gypsy elite' and the 'broad Gypsy masses'.

Having been trained in Gypsy Pedagogical Vocational School, the teachers went to work in the countryside where they were supposed to develop the Gypsy schools. Important source of information about their work and also everyday tasks and problems encountered could be found in the letters exchanged between Nikolay Pankov (one of their trainers), and his students. The most often reported common problem was connected to local authorities who, because of an urgent need for trained teachers also for mainstream (often ethnically mixed) schools mostly in villages, preferred to use the teachers there and not to open new Gypsy schools. Thus, the majority of the trained Gypsy teachers did not in fact do what they had been trained for (to educate Gypsy children) (Druts \& Gessler, 1990, pp. 305-306). To illustrate the above point, we may quote an excerpt from a letter to Nikolay Pankov written by Liuba Miholazhina, who went together with her husband, Dmitriy Kambovich, (also a graduate from the Gypsy pedagogical courses) to work in the Checheno-Ingush Autonomous Soviet Socialist Republic, was appointed in local (non-Gypsy) school and was perceived by local population as ethnic Russian. What makes this letter interesting are the thoughts of the newly-created Gypsy intelligentsia and their social views on Soviet realities:

I strongly dislike those.... who not only do not help their nation but also give it up. I managed to reach the level of the Russians and to prove that we do have abilities too. Now I am working in Caucasus and not among my Gypsies. What made me come here is that I wanted to learn about the life of the Caucasian people. It is very difficult and dangerous to live here. For example, an inspector was murdered today up in the mountains on his way to our regional centre Vedeno. There are many such occurrences here: murders, robberies, raped girls thrown down from the high banks into the river. Going out in the yard at night ... is dangerous because somebody may hit you on the head with a stone. They [the local Chechens-authors note] hate the Russians and treat us as conquerors. They have no idea about the existence of Gypsies and think that I am Russian. (Druts \& Gessler, 1990, pp. 301-302)

\section{The End of Romani Language Education in Soviet Union}

The Government policy towards Gypsies changed radically in 1938. The National Commissariat for Education was reorganised and the responsibility for the peoples living outside own Federal Republics or Autonomous regions or for the people without own ethnic authorities and administrative units was delegated to the authorities of their place of living. On 24 January 1938 the Central Committee of the Communist Party of the Soviet Union (Bolsheviks) issued a Memorandum on the Closing Down of Ethnic Schools and the Ethnic Sections in the Schools. This Memorandum ordered local authorities to close down 18 ethnic sections in the educational system and the existing schools of 16 different nationalities. The nationalities included in the list were selected according to different criteria and ranged from Armenians living outside the Armenian Soviet Socialist Republic, Poles and Germans to Kurds, Assyrians and Gypsies. At the end, all Gypsy schools were closed and the Gypsy children were transferred to the mainstream education system (Demeter et al., 2000, p. 207). The decision to close down the schools of 16 nationalities was a political one, and not based on study of the efficacy of mother-tongue medium teaching or studies comparing it with Russian (or other) medium teaching (and such studies were not conducted at all).

Along with this, the state supported publication of the books in the Romani language ceased and only sporadically folklore texts in academic publications continued to be published. Even the famous Theatre Romen began to use Russian during its performances with only some fragments and songs in Romanes. The new Soviet Gypsy elite accepted only unwillingly this radical change in the state policy. In 1938, the famous Gypsy educator Nikolay Pankov wrote a personal letter to Stalin trying to convince him about the need to continue the 'Gypsy cultural revolution', and to develop further the Romany language and literature, to involve the Gypsies in 'socially useful work', etc. (Druts \& Gessler, 1990, p. 304). It was not before 1941 that NKVD (the People's Commissariat for Internal Affairs) representatives visited Nikolay Pankov to tell him that Comrade Stalin had read his letter and thanked him for it, but the situation didn't change (Kalinin, 2005, pp. 56-57). The graduates of the Gypsy pedagogical courses wrote similar letters too. There was no reply to these letters and there was no change in the state policy towards Gypsy mother tongue education until the collapse of the USSR in 1991.

Both in the past and even nowadays, the assessment of USSR's policies towards the Gypsies, including in the education system, remain highly politicised, often in the spirit of the Cold War, and is pointed as another crime of Stalinism against fundamental human rights (in this case human rights of the Gypsies). In context of our topic we are not discussing the issue from Human rights point of view, but as a unique historical experiment for the creation of a new codified written language for an illiterate internally heterogeneous community speaking different dialects and to establish a comprehensive education system for the education of Gypsy children in their Romani language.

Under the conditions of USSR, this experiment turned out to be unsuccessful, and it was relatively quickly abandoned. Explanations of this failure of Soviet 
policy have to be sought in different directions. On the first place it is because the 'Gypsy issue' itself (i.e., the issue of the overall social integration of Gypsies in Soviet society) is too circumferential for Soviet national politics. After the 1930s, the Soviet state returned to it only in 1956, when a special Decree of the Supreme Soviet of the USSR 'For the inclusion to work of vagrant Gypsies' was passed. By virtue of this decree, the Gypsy nomads (majority of the Gypsies in the USSR at that time) were forced to settle and their speeded social integration (including in the field of education) was realised in a short period of time. The circumstance that Gypsy children were included in the education system without any use of teaching aids in their mother tongue appeared not to be a serious obstacle, and quickly a relatively small circle of Gypsy intelligentsia with good (including university) education came into being. The most famous among them was Professor Georgiy Demeter, Doctor of pedagogical sciences, author of the book Lenin on the Protection of Workers' Health and Physical Culture (Demeter, 1969), which underwent five reprints during the Soviet era and was translated into several languages within the former Soviet bloc (including even two translation into Vietnamese!).

\section{Romani Language in Roma Education and Public Space after WWII}

As far as the very idea of offering to the Gypsies a fullfledged education in their native language-it was completely forgotten soon, and not only in the USSR but worldwide. After the Second World War in the so-called Socialist camp in Eastern Europe, various special educational policies towards Roma were conducted, but none of them involved the use of their mother tongue in education. Similarly, several projects related to the education of local Gypsies were implemented in then Western Europe, but also without making use of the mother tongue in teaching. The first vague attempt at an international level to raise attention to the need of Romani language in schooling was made in 1971 at the meeting, which led to the creation of International Romani Union. Among decisions adopted by the meeting was:

It was agreed that all Gypsy children should receive education in Gypsy culture and (where it was still spoken) in the Romani language. Gypsy teachers should be appointed in schools with large numbers of Gypsy children, where the local population wanted this. Further research should be conducted into the value of caravan schools for nomadic groups. (Kenrick, 1971, p. 104)

The issue of learning and using the Romani mother tongue in the school system has become a reality again after the fall of the communist regimes in the countries of Central, Southeastern and Eastern Europe and the virtual collapse of the socialist camp after 1989. In most of these countries, the right of the Roma (as well as of all other national minorities) to study their mother tongue within the general education system has become legislatively or even constitutionally guaranteed (Bakker \& Rooker, 2001, pp. 1-37; Matras, 2005a, pp. 1-19). In practice, however, in the countries of the region this study is very limited and impermanent (Matras, 2005b, pp. 31-44). This is true even for Romania, where activities to introduce Roma language learning into education and teacher training are relatively more developed as a comprehensive system. In other countries, Romani language teaching is absent or incidental, realised in the framework of individual projects of international organisations (e.g., Save the Children) and mostly local NGOs. Similar project implementations and the introduction of Romani language in education flow in the same time in some countries in Western Europe, such as Sweden and Austria (Englund \& Dalsbro, 2004; Halwachs, 2012a, 2012b).

Here it is necessary to make one important clarification that in these cases it is above all an issue of studying the Romani language within the educational system as an optional subject or in extracurricular forms and it is not about its wider application under different forms of multilingual education. Moreover, in the public sphere, the very idea of autonomous Romani schools with comprehensive education of Roma children entirely in their mother tongue (as it was in Early Soviet Union in 1920s and 1930s) is almost completely absent. It is not envisaged in the numerous national and European programs and strategies, nor in the NGO sector projects. We witnessed only two cases when the usefulness of autonomous Romani schools, versus integration into mainstream schools has been discussed at all. The first case we observed was in 1990 in Bulgaria when a non-Roma NGO (closely connected to renowned international organisation the Minority Rights Group) put the issue of autonomous Romani school as a requirement for the Bulgarian state. The second case is from the beginning of the 21st century, when a group of international Roma activists announced the upcoming opening of the International Roma University in the city of Košice (Slovakia) with full instruction in Romani language. In the latter case, it is obviously about a publicly expressed desire, which was expected to become a self-fulfilling prophecy. Except this announcement nothing more happened, and it has not become clear at all whether somebody really intended to establish such a university. Yet there was no serious public debate about an International Roma University neither in Romani circles, nor in the media. The first case, however, is more interesting because, immediately after the proposal was made, really a heated discussion among the Roma activists in Bulgaria started whether it is necessary to move towards a comprehensive education of Romani children in the Romani language or not. In the end, however, it turned out that almost all (with only one exception-the famous Roma leader Manush Romanov) Roma activists in Bulgaria categorically rejected this idea. 
Their arguments were mainly pragmatic: it will be not only a very expensive, difficult and lengthy process, but it will not help the overall social integration of the Roma, on the contrary, it will even make it harder for them (because the pupils of this type of schools with Romani language teaching will be uncompetitive to their peers who have completed regular mainstream schools with Bulgarian language of instruction). In this way, it turned out that the very idea of comprehensive Romani language school instruction did not meet the support of the Roma community itself and its leaders (and even less of the authorities, who do not bother to discuss it at all), and it sank into oblivion.

Within the framework of national policies and projects of local authorities and the NGOs for the improvement of Roma education in the last quarter of a century have been issued a large number of various Roma-language teaching materials (cf. Bakker \& Daval-Markussen, 2013; Bakker \& Kyuchukov, 2003). This includes both mother tongue primers (e.g., Grigorichenko \& Longvinyuk, 2008; Hübschmannová, 1998; Jusuf, 1996; Kyuchukov, Yanakiev, Malikov, \& Penkov, 1993; Kyuchukov, Yanakiev, \& Iliev 1995; Mānuš, 1996; Sarău, 1994; Zătreanu, 2001) as well as teaching materials with wider content, including materials on Roma history, folklore, literature, and even mathematics (Ionel \& Costin-Ion, 1997, 1999; Kjučukov, 1997, 2000, 2001ab, 2002; Kruezi, 2003; Sarău, 2005a, 2005b, 2005c; Sarău \& Stănescu, 2005). These teaching resources target the Roma in the respective countries (or in individual localities), but there are also internationally oriented materials supported by international institutions such as the Council of Europe (Kurtiàde, 1992, 1994). Parallel with this in Romani are translated numerous texts, e.g., international, European and national human rights documents, charters, resolutions, reports, etc. Similarly to publications in Romani in early Soviet Union they are mostly unread.

The common thing also among all educational publications is that they all targets Roma with a command of literacy in their respective national or state language (Matras, 1999, p. 482), and are used only for a certain time and only by a limited circle of Roma children encompassed in frames of specific projects (or even are only published and are not used at all), and after completion of the projects concerned, they are abandoned and forgotten. The only exception here again is Romania, where the published teaching materials are in constant use, but also there only a relatively low number of Roma pupils are attracted (compared to the number of Roma children included into general education system).

Looking across national frameworks, the panEuropean institutions (and primarily the European Commission and the Council of Europe) are eager to support, direct and coordinate the programs and the projects to improve Roma schooling, but face a number of problems, and little is achieved in this respect (see New, Hristo Kyuchukov, \& de Villiers, 2017). The European
Charter for Regional or Minority Languages (1992) applies for Romani too and even more, Romani is included in the list of minority languages in need of protection and promotion. The Charter, however, is not signed or ratified by all member states of Council of Europe and only 16 states that have ratified it, apply it to Romani: Austria, Bosnia and Herzegovina, Czech Republic, Finland, Germany, Hungary, Montenegro, Netherlands, Norway, Poland, Romania, Serbia, Slovakia, Slovenia, Sweden, Ukraine. The Charter's education article (Part III, article 8) applies to even less countries: Bosnia and Herzegovina, parts of Germany, Hungary, Montenegro, Poland, Serbia and Slovakia (Application of the European Charter for Regional and Minority Languages, 2016); however, also there, a real implementation of the article 8 is yet to be achieved. Roma education is pointed as one of the main priorities in EU Framework for National Roma Integration Strategies (European Commission, 2011), and in the respective National Strategies too. The decision as to how and in which extent Roma language should be used in national education systems, however, remains a prerogative of individual states and the responsibility rests with individual governments, which in many cases are unwilling to deal with this issue at all. Therefore, despite numerous recommendations from linguists and educators pointing to the usefulness of learning mother tongue (cf., Matras, 2005b, p. 42), the European policy as a whole can be defined as very cautious and inconsistent.

Apart from the reluctance of the authorities, another significant obstacle for introducing Romani language as part of multilingual education is the lack of its standardisation and codification on a national and international level, despite long-standing discussions between Roma activists and numerous attempts in this direction (see Kyuchukov, 2016, pp. 63-80; Matras, 1999, pp. 481-502; Friedman, 2001, pp. 103-133). The only one exception is the Slovak Republic, where in 2008 Romani language was officially standardised with a state act, but nothing followed. In fact, Romani language continues to function as a system of more or less distinctive dialects (even within a country), and for large parts of the Roma in Central, Southeastern and Eastern Europe it is not a mother tongue at all, and their native language could be also Turkish, Greek, Albanian, Serbian, Bulgarian, Romanian, Hungarian, Ukrainian, etc. (Marushiakova \& Popov, 2015, pp. 26-54). Even the alphabets used for writing the Romani language differ. Most commonly, in the teaching materials an adapted version of the country's alphabet is used, but there are some exceptions, for example, in Romania is used the uniform 'polylectal' Roma alphabet, created by the French linguist Marcel Courthiade (1992, p. 9), and in Bulgaria (in order to underline transnational character of Romani language) an adapted version of the Latin alphabet is used rather than Cyrillic used by Bulgarian speakers.

Nevertheless, in the absence of a standardised codified language, something like Romani lingua franca emerged during last 2-3 decades among small circle of 
international Romani activist used for communication among speakers of different Roma dialects at gatherings in Budapest, Strasbourg, Brussel or elsewhere. Similar communicative lingua-franca, composed by mixture of dialects and/or using simultaneously more than one dialectal variety accompanied by introduction of adapted international words, is used also in written form (Matras, 1999, pp. 481-502). This is characterised by some linguist as 'emergence of linguistic pluralism' and use of the linguistic pluralism in Roma language policy, including in language education is recommended (Matras, 2005b, pp. 43-44). Till now, however, no official institution nor Roma organisations or Roma authors took a stand on this recommendation. Against this backdrop, however another proposal was made recently-to accept English language as an international language for the Roma around the world that will enable them to 'build a truly international Romani community' (Lee, 2017). According to the author of this proposal, this must be done through the programs of the Central European University in Budapest which are funded by the Open Society Institute of the famous billionaire George Soros and are central for Roma empowerment.

Returning to the issue of the use of the Romani language in the framework of the contemporary education system in Europe, it can be summed up that it is being implemented only on very limited scale and in diverse forms. The reasons for this state of affairs is varied, and they should not be confined to the reluctance of individual nation states to seriously engage in this issue and to difficulties connected with the specificities of Romani language and lack of trained teachers. This is only one side of the issue, but there is another one-the lack of real interest on the part of the Roma themselves in such a type of education where the teaching of the main subjects will be in the Romani language. This is not an expression of kind of aspirations for voluntary assimilation, but simply a pragmatic approach by parents to the future of their children, whose future professional and social realisation will inevitably be not within the Roma community but within the framework of a macro-society in which they live. Therefore, in the Central, Southeast and Eastern Europe it is common that parents deliberately decide not to speak in Romani with their young children wanting their first language to become the language of the country, in which they live and Romani to be their second language. Particularly noteworthy is that the leading Roma activists (both national and international ones) understand and share this position. The leading Romani political activists Andrzej Mirga and Nicolae Gheorghe wrote about the introduction of manuals for teaching Romani: 'How will it enable these children to advance beyond their parents' status in the future? What prospects will it open to them in a modern world ruled by achievement and competition?'; 'the education in Romani language would strengthen their ethnicity, but it would also limit opportunities for overcoming the inherited underdevelopment of the Roma and for diminishing the gap between them and the majority' (Mirga \& Gheorghe, 1997, p. 22).

\section{Conclusion}

As it became clear from what has been said so far, at this stage, the idea of an autonomous Roma education (as in the early USSR) is totally unacceptable for Roma themselves. The parents' and main Roma activists' reluctance to have mother-tongue based multilingual education indicates that they are trapped in the pursuit of noble purpose of achieving social integration and in their quest to go out from the limits of often segregated and unequal education. This leads to neglecting of massive world-wide research on mother-tongue based multilingual education and positive results from it in both general school achievement and even the knowledge of the country's official language. ${ }^{5}$

The opportunities for Romani children to be taught at least partially in the Romani language, in present-day Europe, in spite of efforts of some stakeholders and of minority laws, are still limited. Whether it will come a time when this idea will be revived again, or whether linguistic pluralism or some form of multilingual education will be adopted, it is difficult at present to foresee.

In any case, the importance of the social experiment in the field of Roma education in the early USSR in the 1920s and 1930s remains part of the history of Roma, as well as part of the history of education.

\section{Acknowledgments}

This article is written as a part of the research project 'Romalnterbellum. Roma Civic Emancipation between the Two World Wars' which has received funding from the European Research Council (ERC) under the European Union's Horizon 2020 research and innovation programme (grant agreement No 694656). It reflects only the authors view and the agency is not responsible for any use that may be made of the information it contains.

\section{Conflict of Interests}

The authors declare no conflict of interests.

\section{References}

Anonymus. (1933). Amaro znamyo-Lenino [Our Banner-Lenin]. Moscow: OGIZO-GAIZOI.

Application of the European Charter for Regional and Minority Languages. (2016). Retrieved from https:// www.coe.int/t/dg4/education/minlang/sgreports/SG report2015_en.pdf

Bakker, P., \& Daval-Markussen, A. (2013). Romani iden-

\footnotetext{
${ }_{5}^{5}$ Similarly neglected are also the rare works of individual Roma scholars in this direction. See Kyuchukov (2014, pp. 211-225, 2017, pp. 290-300) and Kyuchukov, Samko, Kopcanova and Igov (2016, pp. 50-62).
} 
tity in Romani language teaching materials: Visual and linguistic aspects. Romldent Working Papers Paper, 21. Retrieved from http://romani.humanities. manchester.ac.uk/virtuallibrary/librarydb//web/files /pdfs/376/Paper21.pdf

Bakker, P., \& Kyuchukov, H. (2003) Publications in Romani, useful for Romani language education. Preliminary and Experimental Edition. October 2003/Publikacie andi Romani čhib kaj si lačhe andar i edukacia pal i Romani čhib. Angluni thaj eksperimentalno edicia. Octobr 2003. Retrieved from http://www.hum. au.dk/lingvist/lokal/pdf/romedu-prefinal-november20.pdf

Bakker, P., \& Rooker, M. (2001). The political status of the Romani language in Europe. Mercator Working Papers 3. Retrieved from http://www.utopiadream. info/educarom/educarom/doc/02romani_language. pdf

Berlyando, A. S. (1931). Pervo pomoshch dro nabkhtalo sluchyai [The first aid in case of accident]. Moscow: Tsentroizdat.

Bezlyudsko, M. (1932a). So diya sovetsko vlast romanechyake [What the Soviet rule gave to the Gypsy girls]. Moscow: Tsentroizdat.

Bezlyudsko, M. (1932b). Phagirdo desto. Romane rosphenibena [The broken whip. Short stories]. Moscow and Leningrad: Khudozhestvennaya literatura.

Bezlyudsko, M. (1932c). Mishko oktyabryonok [Mishko, the little Octobrist] Moscow: Terni gvardiya.

Bezlyudsko, M. (1933). Nevo dzhiiben. Gilya [New life. Poems]. Moscow: Terni gvardiya.

Courthiade, M. (1992). Research and action group on Romani linguistics. Interface, 8, 4-11.

Crowe, D. (1996). A history of the Gypsies of Eastern Europe and Russia. New York: St. Martin's Griffin.

Demeter, G. (1969). Lenin ob okhrane zdorovya trudyashchikhsya i fizicheskoi kulture [Lenin about the protection of workers health and physical culture]. Moscow: Fizkultura i sport.

Demeter, N., Bessonov, N. H., \& Kutenkov, V. (2000). Istoriya tsigan. Novyi vzglyad [History of the Gypsies. A new look]. Voronezh: Institut etnologii I antropologii RAN.

Dmitrievo, S. (1935). Pal mamontoste [About the mammoth]. Moscow: Gosudarstvenno uchebno-pedagogicheskoe izdatelstvo.

Druts, E., \& Gessler, A. (1990) Tsigne. Ocherki [The Gypsies. Essys]. Moscow: Sovetskiy pisatel.

Dudarova, N. A. (1928). Nevo drom (bukvaryo) vash bare manushenge [New way (a primer) for adult people]. Moscow: Tsentrizdat.

Dudarova, N. A. (1929). Palo vlast soveten. E biblioteka vash nabut siklyarde manushenge [About Soviet's rule. A library for not sufficient educated people] Moscow: Tsentrizdat.

Dudarova, N. A (1932a). Drom ko siklyaiben. Lilvari vash nabut siklyakirdenge [Way to learning. Text-book for the not sufficient educated ones]. Moscow: Uchpedgiz.
Dudarova, N. A. (1932b). Amari buti. Bukvaryo vash pervo bersh siklyaibe [Our work. The primer for the first year of schooling]. Moscow: Uchpedgizo.

Dudarova, N. A. (1933). Rodno chib. Vash pervo bersh siklyaiben [Mother tongue. For the first year of schooling]. Moscow: Uchpedgizo.

Dudarova, N. A. (1934). Avasa lilvarensa. Bukvaryo vash bare manushenge [Let's be literate. Primer for adult people]. Moscow: Uchpedgizo.

Dudarova, N. A., \& Pankov, N. (1928). Nevo drom. Bukvaryo vash bare manushenge [New way. Primer for adult people]. Moscow: Tsentrizdat.

Dudarova, N. A., \& Pankov, N. (1930). Dzhiidi buti. Romano bukvaryo vash1 bersh siklyaiben [Living work. Roma primer for the first year of schooling]. Moscow: Tsentrizdat.

Englund, C., \& Dalsbro, A. (2004). Roma in public education. Stockholm: RAXEN, National Focal Point for Sweden. Retrieved from http://expo.se/www/ download/roma-sweden.pdf

European Commission. (2011). EU framework for national Roma integration strategies up to 2020. Retrieved from http://ec.europa.eu/justice/policies/ discrimination/docs/com_2011_173_en.pdf

European Charter for Regional or Minority Languages. (1992). Retrieved from http://www.coe.int/en/web/ conventions/full-list/-/conventions/rms/090000168 0695175

Fedorovskiy, I. M. (1933). Dre rozrodibe palo timinitka minerali te rudy [On the extraction of useful minerals and ores]. Moscow: Narkomtyazhpromo.

Friedman, V. A. (2001). Romani as a minority language, as a standard language, and as a contact language: Comparative legal, sociolinguistic, and structural approaches. In K. Fraurud \& K. Hyltenstam (Eds.), Multilingualism in global and local perspectives (pp. 102-133). Stockholm: Stockholm University.

GARF (Gosudarstvennyi arkhiv Rossiyskoi Federatsii/State Archive of the Russian Federation). $f$. P-1235, o. 127, d. 8.

Germano, A. (1930). Atasyatuno burmistro [Yesterdays's leader]. Moscow: Tsentrizdato.

Germano, A. (Ed.). (1931). Almanakho romane poeten. [Almanac of Roma poets]. Moscow: Tsentrizdato.

Germano, A. (1932). Romano theatro. Khelibena. Dzhiiben pre roty. Mashkir jaga. Palaga pervo [Roma theatre. Lullabies. Life on the wheels. Between fires. Palaga is the first]. Moscow: Khudozhestvennaya literatura.

Germano, A. (Ed.). (1934). Romano almanakho [Roma almanac]. Moscow: Goslitizdat.

Germano, A. (1935). Ganka Chyamba i vavre rosphenibena [Ganka Chyamba and other stories]. Moscow: Khudozhestvennaya literatura.

Germano, A. (1938). Neve gilya [New poems]. Moscow: Khudozhestvennaya literatura.

Gorko, M. (1932). Makar Chyudra i vavre rosphenibena. [Makar Chudra and other stories]. Moscow: ГИХЛ. 
Gorky, M. (1931). Koli vrago na zdelape les khaskirna [If the enemy does not surrender, he is destroyed]. Moscow: Tsentrizdato.

Grigorichenko, S., \& Longvinyuk, T. (2008) God'avoro dromoro [Wise little way]. Lutsk: VAT.

Halwachs, D. W. (2012a). Romani teaching in Austria. Journal of Ethnic Studies, 68, 34-51.

Halwachs, D. W. (2012b). Romani teaching in Europe: Some general considerations based on model cases. European Yearbook of Minority Issues, 9, 249-269.

Hirsch, F. (2005). Empire of Nations: Ethnographic knowledge and the making of the Soviet Union. Ithaca, NY: Cornell University Press.

Hübschmannová, M. (1998). Amari abeceda. Naše abeceda. Prague: Fortuna.

Ilyinsko, M. (1932). Raskiro podipena. Rozphenibena [Master's pittance. Short stories]. Moscow and Leningrad: Khudozhestvennaya literatura.

Ilyinsko, M. (1934). Shatritko jag [The fire of tent]. Moscow: Khudozhestvennaya literatura.

Ionel, I., \& Costin-Ion, M. (1997). Aritmetică. Aritmetika. Clasa I. I jekhto klasa. Manual bilingv preparator pentru elevi rromi. Duje hibutni angliśkolaqi pustik vaś e rromane siklŏvne. Târgu Mureş: Fundația 'Pro Europa'.

Ionel, I., \& Costin-Ion, M. (1999). Aritmetică. Aritmètika. Clasa a II-a. I dujto klàsa.Manual bilingv preparator pentru elevii rromi. Dujećhibutni angliśkolaqi pustik vaś e rromane siklŏvne. Bucharest: Fundația 'Phoenix'.

Jusuf, Š. (1996). Sikljova Romani čhib [To learn Romani language]. Skopje: Prosvetno delo.

Kalinin, V. (2005). Zagadka baltiyskikh tsigan. Ocherki istorii, kulturi i sotsialnogo razvitia baltiyskikh tsigan [The enigma of the Baltic Gypsies. Essays on the history, culture and social development of Baltic Gypsies]. Minsk: Logvinov.

Karpinsko, V. (1934). Rakiribe vash leninizmo [Conversation about Leninism]. Moscow: Partizdato.

Kenrick, D. (1971). The world Romani congress-April, 1971. Journal of the Gypsy Lore Society, 50(3), 101-108.

Kenrick, D. (2007). The Romani world: A historical dictionary of the Gypsies (Romanies). Hatfield: University of Hertfordshire Press.

Khrustalyov, V. (1936). Gilya [Poems]. Moscow: Khudozhestvennaya literatura.

Kjučukov, X. (1997). Amari Romani Lumja. 1 kotor. Romane poeme e tikne čavorenge [Our Romani world. Part 1. Romani poems for small children]. Sofia: Business Bridge.

Kjučukov, X. (2000). Amari Romani Lumja. 2 kotor. Romane paramise e tikne čhavorenge [Our Romani world. Part 2. Romani fairy-tales for small children]. Sofia: Tilia.

Kjučukov, X. (2001a). Amari Romani Lumja. 3 kotor. Romane gilja e tikne čhavorrenge [Our Romani world. Part 3. Romani songs for small children]. Sofia: Iktus.
Kjučukov, X. (2001b). Amari Romani Lumia. 4 kotor. Romane gogjaver thaj garavde lava [Our Romani world. Part 4. The Romani wise and hidden words]. Sofia: Iktus.

Kjučukov, X. (2002). Me ginav dži ko deš [I count to 10]. Sofia: Iktus.

Kruezi, S. (2003). Matematika 1. Vash Funduni Shkola [Maths 1. For basic school]. Copenhagen: EUROMA.

Kurtiàde, M. (1992). Sirpustik amare ćhibăqiri [The Primer of our language]. Toulouse: Centre national de documentation pédagogique \& Besièrs: Agéncia Occitana de comunicacion.

Kurtiàde, M. (1994). Sikavipen sar te siklon e chavorre e sirpustikaça [Instruction how to use the primer to teach the children]. Toulouse: Centre régional de documentation pédagogique de Midi-Pyrénées.

Kyuchukov, H. (2014). Acquisition of Romani in a bilingual context. Psychology of Language and Communication, 18(3), 211-225.

Kyuchukov, H. (2016). Roma language: Problems of its codification. In E. Marushiakova \& V. Popov (Eds.), Roma culture: Myths and realities (pp. 63-80). Munich: Lincom Academic Publisher.

Kyuchukov, H. (2017). Cultural-ecological theory and the language education of Roma children. RUDN Journal of Psychology and Pedagogics, 14(3), 290-300.

Kyuchukov, H., Samko, M., Kopcanova, D., \& Igov, P. (2016). The knowledge of Romani and school readiness of Roma children. East European Journal of Psycholinguistics, 3(2), 50-62.

Kyuchukov, H., Yanakiev, M., \& Iliev, D. (1995). Romani alfabeta. Romska azbuka [The Roma alphabet]. Sofia: Bulvest-2000.

Kyuchukov, H., Yanakiev, M., Malikov, Y., \& Penkov, B. (1993). ABC lil. Romski bukvar [ABC book. Roma Primer]. Sofia: Zefir.

Lebedevo, G. (1930). Neve glosa. Gilya i rakirribena [New voices, Poetry and stories]. Moscow: Tsentrizdato.

Lee, J. (2017). CEU and NGO crackdown: A double blow for Roma inclusion in Hungary. OpenDemocracy. Retrieved from https://www.opendemocracy.net/ can-europe-make-it/jonathan-lee/ceu-and-ngo-crack down-double-blow-for-roma-inclusion-in-hungary

Levi, M. F. (1935). Dzhuvlyakiri gigiena [Women hygiene]. Moscow and Leningrad: Biomedgizo.

Mānuš, L. (1996). Romani čhib ābeca [The Romani language $A B C]$. Riga: Sprīdītis.

Martin, T. (2001). The affirmative action empire: Nations and nationalism in the Soviet Union, 1923-1939. Ithaca, NY: Cornell University Press.

Marushiakova, E., \& Popov, V. (2015). Identity and language of the Roma (Gypsies) in Central and Eastern Europe. In T. Kamusella, M. Nomachi \& C. Gibson (Eds.), The Palgrave handbook of slavic languages, identities and borders (pp. 26-54). London: Palgrave.

Marushiakova, E., \& Popov, V. (2016). Gypsies of Central Asia and Caucasus. London: Palgrave Macmillan.

Matras, Y. (1999). Writing Romani: The pragmatics of 
codification in a stateless language. Applied Linguistics, 20(4), 481-502.

Matras, Y. (2005a). The status of Romani in Europe. Report submitted to the Council of Europe's Language Policy Division, October 2005. Retrieved from http:// romani.humanities.manchester.ac.uk/downloads/1/ statusofromani.pdf

Matras, Y. (2005b). The future of Romani: Toward a policy of linguistic pluralism. Roma Rights Quarterly, 1, 31-44. Retrieved from http://www.errc. org/article/the-future-of-romani-toward-a-policy-oflinguistic-pluralism/2165

Merime, P. (1935). Karmen. Moscow: Goslitizdato.

Mirga, A., \& Gheorghe, N. (1997). The Roma in the twenty-first century: A Policy paper. Princeton, NJ: Project on Ethnic Relations.

New, W. S., Hristo Kyuchukov, H., \& de Villiers, J. (2017). 'We don't talk Gypsy here': Minority language policies in Europe. Journal of Language and Cultural Education, 5(2), 1-24. Retrieved from https:// www.degruyter.com/downloadpdf/j/jolace.2017.5. issue-2/jolace-2017-0015/jolace-2017-0015.pdf

Nikitino, A. I., Polyakovo, \& others (1932). Matematika. Vash pervo bersh [Maths. For the first year]. Moscow: Uchgizo.

O’Keeffe, B. (2013). New Soviet Gypsies: Nationality, Performance, and selfhood in the early Soviet Union. Toronto: University of Toronto Press.

Orlova, E. (1933). Pre felda murdyona yaga. Gilya [In the field the light go out. Poems] Moscow: Khudozhestvennaya literatura.

Pankova, O. (1933). Amare divesa, Gilya [Our days, Poems] Moscow and Leningrad: Khudozhestvennaya literature.

Pankova, O. (1936). Rostasado dzhiiben. Poema [Crushed life. A poem]. Moscow: Khudozhestvennaya literatura.

Pankova, O. (1938). Gilya [Poems]. Moscow: Khudozhestvennaya literature.

Pankovo, N. A. (1933). Khrestomatiya piro literature. Vash shtarto bersh siklyaibe [Chrestomathy in literature. For 4th year of schooling]. Moscow: Uchpedgizo.

Pankovo, N. A. (1934). Bukvaryo vash nalilvare manushenge [Primer for illiterate people]. Moscow: Gosudarstveno uchebno-pedagogicheskoe izdatelstvo.

Perepisi naselenia Rossiiskoi imperii, SSSR, 15 novikh nezavisimikh Gosudarstv. (2012). Demoskop Weekly, 673-674. Retrieved from http://demoscope.ru/ weekly/ssp/Census.php?cy=7

Polyakova, M. (1929). Sir Rom Pupirka skediyape Romano soyuzo, dre Moskva [How Rom Pupirka went to Roma union in Moscow]. Romni zorya, 2, 49.

Polyakova, M. (1930). Sir Rom Pupirka skediyape, ke Roma dre Moskva. [How Rom Pupirka went to Roma in Moscow]. Romni zorya, 3-4, 63.

Polyakova, M. (1931). Romane rakiribe [Romani conversation]. Moscow: Tsentrizdato.
Pushkin, A. S. (1937a). Kapitanoskiri chyai [The Captain's daughter]. Moscow: Goslitizdat.

Pushkin, A. S. (1937b). Roma [The Gypsies]. Moscow: Goslitizdato.

Rom-Lebedev, I. (1930). Baxt. Rasskaz [Luck. A story]. Moscow: Tsentrizdato.

Rom-Lebedev, I. (1931). Kham dre blata [The sun in the swamp]. Moscow: Tsentrizdato.

Rom-Lebedev, I. (1990). Ot tsiganskogo khor $k$ teatru 'Romen' [From the Gypsy choir to the theater Romen]. Moscow: Iskusstvo.

Rusakov, A., \& Kalinin, V. (2006). Literatura na tsiganskom yazike v SSSR: 1920-30-e gody [Literature in Roma language in USSR: 1920s-1930s] In O. A. Abramenko (Ed.), Issledovaniya po severnorusskomy dialektu tsiganskogo yazyka (pp. 266-287). Saint Petersburg: Anima.

Sarău, G. (1994). Limba romani (țigănească). Manual pentru clasele de învățători romi ale Școlilor Normale. Bucharest: Didactica și Pedagogica.

Sarău, G. (2005a). Limba şi literatura rromani. Manual pentru clasa I. I rromani ćhib thaj i literature vaś $i$ jekhto klasa. Bucharest: Sigma.

Sarău, G. (2005b). Limba şi literatura rromani. Manual pentru clasa a III-a. I rromani ćhib thaj i literatura vaś i trinto klasa. Bucharest: Sigma.

Sarău, G. (2005c). Limba şi literatura rromani. Manual pentru clasa a IV-a. I rromani ćhib thaj i literatura (vaś i śtarto klasa). Bucharest: Sigma.

Sarău, G., \& C. Stănescu. (2005). Limba şi literatura rromani: manual pentru clasa a II-a. I rromani ćhib thaj i literatura vaś i dujto klasa. Bucharest: Sigma.

Sergievskiy, M. V. (1931). Tsiganskiy yazik. Kratkoe rukovodstvo po grammatike i pravopisaniu [Gypsy language. A short guide to grammar and spelling]. Moscow: Tsentrizdat.

Sergievskiy, M. V., \& Barannikov, A. P. (1938). Tsiganskorusskiy slovar. [Gypsy-Russian disctionary]. Moscow: Gosudarstvennoe izdatelstvo inostrannykh i natsionalnikh slovarey.

Slezkine, Y. (1994). The USSR as a communal apartment, or how a socialist state promoted ethnic particularism. Slavic Review, 53(2), 414-452.

Suny, R. G., \& Martin, T. (Eds.). (2002). A state of nations: Empire and nation-making in the age of Lenin and Stalin. New York: Oxford University Press.

Svetlovo, L. (1938). Rom Kvasyu. [Rom Khvasyu]. Moscow: Khudozhestvennaya literatura.

Taranovo, A. (1932). Amari zor. Obshchestvenno dzhiniben vash III bersh [Our strenght. Social studies for 3rd year]. Moscow: Uchpedgizo.

Terekhova, L. G., \& Erdely, V. G. (1934). Georgrafiya. Uchebniko vash nachyalnio shkola. Chyast pervo [Gheography. Text-book for elementary school. Part One]. Moscow: Gosudarstvenno uchebno-pedagogicheskoe izdatelstvo.

Tetyurev, V. A. (1935). Estestvenoznaniyo. Lilvari vash nachyalno shkola vash bare manushenge [Natu- 
ral science. Text-book for elementary school for adults]. Moscow: Gosudarstvenno uchebno-pedagogicheskoe izdatelstvo.

Tolstoy, L. N. (1933). Trin richa [Three bears]. Moscow and Leningrad: Detgizdat TsK VLKSM.

Tolstoy, L. N. (1936). Koli progiya balo [After the ball]. Moscow: Gostlitizdato.

Venttsel, T. V., \& Germano, A. V. (1937). Lilvari piro romani chib. Vash 1 i 2 klase Dre nachyalno shkola. Pervo chyast. [Textbook on Romani language. For the 1 and 2 classes. For elementary school. First part]. Moscow: Gosudarstvenno uchebno-pedagogicheskoe izdatelstvo.

Wixman, R. (1984). The peoples of the USSR: An ethnographic handbook. Armonk, NY: M. E. Sharp.

Zahova, S. (2014). History of Romani literature with multimedia on Romani kids' publications. Sofia: Paradigma.

Zătreanu, M. (2001). ABĆ. Anglutno lil [ABC. The first book]. Bucharest: Veritas.

\section{About the Authors}

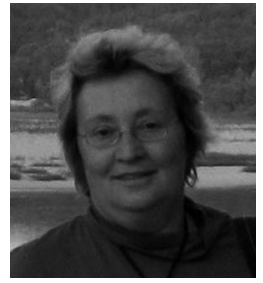

Elena Marushiakova works at School of History at the University of St. Andrews. She has worked in the field of Romani studies for more than three decades and published widely on Roma in Bulgaria, Balkans and Central and Eastern Europe. Her major publications (in co-authorship with Vesselin Popov) include the first-ever monograph on Roma history and ethnography of the Roma in Bulgaria (1997), on the Roma in the Ottoman Empire (2000); alongside a book on Roma in the Black Sea region (2008) and book on Gypsies in Central Asia and Caucasus (2016). Elena is President of the Gypsy Lore Society, which is the world's oldest organization of Romani studies.

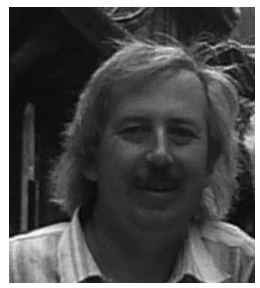

Vesselin Popov works at School of History at the University of St. Andrews. He has worked in the field of Romani studies for more than three decades and published widely on Roma in Bulgaria, Balkans and Central and Eastern Europe. His major publications (in co-authorship with Elena Marushiakova) include the first-ever monograph on Roma history and ethnography of the Roma in Bulgaria (1997), on the Roma in the Ottoman Empire (2000); alongside a book on Roma in the Black Sea region (2008) and book on Gypsies in Central Asia and Caucasus (2016). 